\title{
Local Tax Scale and Its Economic Effects in China
}

\section{Feiyang Chang}

School of Economics, Jinan University, Guangzhou, China

Email: cfyang2014@163.com

How to cite this paper: Chang, F.Y. (2017) Local Tax Scale and Its Economic Effects in China. Modern Economy, 8, 445-457. https://doi.org/10.4236/me.2017.83033

Received: January 22, 2017

Accepted: March 26, 2017

Published: March 31, 2017

Copyright $\odot 2017$ by author and Scientific Research Publishing Inc. This work is licensed under the Creative Commons Attribution International License (CC BY 4.0).

http://creativecommons.org/licenses/by/4.0/

\begin{abstract}
As the most important part of local fiscal revenue, the local tax scale will have an impact on the local economy. This paper takes 343 cities in China as the research object, makes an empirical study about the impact of local taxation on economic growth. From the perspective of regional development, the effect of raising the scale of local tax on the economic growth in the eastern region is the largest, followed by the northeastern region and the central region, and the economic growth in the western region is the least significant.
\end{abstract}

\section{Keywords}

Local Tax, Local Tax Revenue, Economic Growth

\section{Introduction}

Local tax revenue refers to the portion of the tax revenue that is used by the local government, specifically the local tax and the part of the shared tax. As the most important component of local fiscal revenue, the size of local tax revenue will inevitably affect the local economic development. At present, the size of local tax revenue in China, the current scale of the local economy has played a positive role or negative role is an important issue that we need to study.

For a long time, the foreign scholars' research on the relationship between tax scale and economic development has focused on the macro level, which is the impact of national macro tax burden on economic growth. Different scholars have different points of view about the basic theory. Classical economists, such as Adam Smith, argue that economic freedom creates efficiency and encourages the government to impose light tax policies to reduce the obstacles to economic development. With the development of economy and the emergence of the economic crisis, the Keynesian school put forward that taxation can become an effective means to stimulate the effective demand and regulate the distribution of 
wealth, to maintain economic stability and promote economic development. In the 1970s, with the emergence of stagflation, taxation became the main culprit that dampened private investment and labor and thus affected the economy. So, the supply-side school proposed the use of a low tax base to increase the demand and supply of the capital. Arthur Betz Laffer, the representative of the Laffer curve, proposed that there is an optimal macro tax burden, which can make the economic growth rate reached the maximum. With the continuous development of economic society, the macro tax burden on the role of economic growth is also more diverse and complex, and its related theory is constantly expanding and improving.

In the empirical aspect, western scholars have different conclusions from different angles. Some scholars' research shows that the tax burden is not a significant impact on economic growth; for example, Koester and Kormendi (1989) [1] analyzed the data of 63 countries and found that neither the average effective tax burden nor the marginal effective tax burden will lead to significant growth of national income. Study on some other scholars show that the tax burden is negatively related to economic growth. Through learning the tax data of 21 national, K. Marsden (1983) [2] found that when the ratio of tax revenue and the GDP increase $1 \%$, the economic growth rate will decline $0.36 \%$. After examining the GDP growth rates and tax rates of 11 OECD countries from 1960 to 1992, Karras (1999) [3] used four dynamic time series models to obtain that a higher tax rate permanently lower the GDP at steady-level, but only have a temporary change in economic growth, with no permanent impact. Some scholars through establish models to calculated the most suitable tax burden which can maximize economic growth. For example, Scully (1993) [4] established the time series model by studying the relationship between macro tax burden and economic growth in the United States from 1929 to 1989, and calculated the optimal macro tax rate between $21.5 \% \sim 22.9 \%$ can maximizing the economic growth. Scully (1996) [5] also found that a tax rate of $19.7 \%$ could maximize New Zealand's economic growth by $20.2 \%$. The domestic scholars also conducted similar study, Guo Qingwang, Lv Bingyang (2004) [6] through their model they get conclusion that marginal macro tax rate increased $1 \%$, the economic growth rate reduce by $0.027 \%$. Wang Junping (2005) [7] showed that the macro tax burden increased by $1 \%$ between 1985 and 2004, GDP growth rate will decline $0.02 \%$. Foreign theory development earlier and relatively mature, usually using mathematical model with the empirical method; because of different periods the tax has different function, the research of macro tax burden and economic growth in our country starts late, and the empirical study is more commonly used purely quantitative analysis.

As a core part of national finance, taxation analysis of its impact on economic growth can help to grasp the overall economic situation of the country. In the background of the tax-sharing fiscal system, the local tax revenue is regarded as a part of national tax, which is the main support of the local finance, its size will inevitably affect the local economy, thus affecting the entire national economic 
development. China's current relationship between local tax revenue and economic growth are concentrated in the following aspects: first, the theoretical analysis of the reasonable scale of local tax. Xu Jianguo, Ye Qing (1998) [8] pointed out that to determine the reasonable size of local taxation, it should be considered that whether it is compatible with China's political and economic system, if it can meet the needs of local governments to fulfill their necessary functions, is it able to promote local economic development, if it is consistent with the strategic objectives of the tax sharing system and whether it is more efficient than other forms of financing. Shi Yuqiang, Ma Li (1998) [9] through theoretical proof and data enumeration analysis, concludes that the ratio of local tax revenue and GDP is low in Heibei Province. Second, the research on the relationship between the growth of local tax revenue and economic growth rate. $\mathrm{Li}$ Dan, Cao Jianxin (2006) [10] have shown that the growth rate of local tax revenue in Guangdong Province is from high to low in 1995-2004, and is approaching to the growth rate of GDP. Third, the impact of local tax revenue on economic growth. Ma Shuanyou (2001) [11] obtained the conclusion that lower the marginal tax rate can promote economic growth by cross-sectional regression of the local marginal tax rate and regional economic growth rate in 1994-1998 and use this conclusion to explain the reason why the western region has a slowly economic development space.

It can be seen from the existing literature that the study of domestic scholars on the relationship between local tax revenue and economic growth are far less than the relationship between macro tax burden and economic growth, and most of them are concentrated in one province or region. The research methods are focused on theoretical analysis and data interpretation, empirical analysis is not sufficient. The exploration of the relationship between the scale of local tax and economic growth has great theoretical and practical value to the construction of local tax system and economic development in China. This paper takes the whole country as the research object, through the analysis of the existing local taxation scale, using the theoretical exposition and empirical study to reveal its impact on the local economy.

\section{China's Local Tax Scale}

In our country, with the reform of the tax system in 1994, the local tax system was formed in the real sense. Since the local tax has become the main financial support of the local government to exercise the powers, after more than 20 years' development and perfection, the tax division between central and local governments is as shown in Table 1. As can be seen, local tax revenues are made up within two parts. Similar with the macro tax burden, local tax revenues burden, or can be say local tax income size, can be defined as local tax revenues/local GDP.

To study the impact of local tax revenue on economic growth, it is necessary to make clear that local tax revenue is an integral part of national tax revenue, and its scale is closely related to the overall tax revenue of the country. As can be 
seen from Table 2, in recent years, China's macro tax burden continues to increase. Until 2013, small-caliber macro tax burden has reached 19.43\%, higher than most scholars have inferred reasonable range. The proportion of local tax revenue to GDP has been increasing year by year, and the proportion of it to tax revenue in the whole country has been increasing, which to some extent reflects that the tax revenue is tilted slowly to the local government. From the relationship between taxation and fiscal expenditure we can see that the national tax revenue provides nearly 80 percent of the state's fiscal expenditure, local taxes account for less than 50 percent of the local fiscal expenditure, while the local government's financial expenditure burden of the national fiscal expenditure $85 \%$, which shows that there is a serious non-reciprocal between local power and financial rights, local tax revenue is far from meeting local spending needs.

Table 1. The current division of tax revenue in china.

\begin{tabular}{|c|c|c|}
\hline Central tax & Local tax & Sharing tax \\
\hline $\begin{array}{l}\text { Tariff; } \\
\text { consumption } \\
\text { tax; vehicle } \\
\text { purchase tax; } \\
\text { customs import } \\
\text { value-added tax }\end{array}$ & $\begin{array}{l}\text { Urban land use tax; arable land } \\
\text { occupation tax; land value-added tax; } \\
\text { property tax; travel tax; deed tax; } \\
\text { Business tax (railway, bank head } \\
\text { office, insurance companies and } \\
\text { other centralized payment to the } \\
\text { central and other to the local); } \\
\text { personal income tax (in addition to } \\
\text { deposit interest income from } \\
\text { personal income tax, the rest part has } \\
\text { the same share proportion with the } \\
\text { enterprises income tax); resource tax } \\
\text { (offshore oil companies return to the } \\
\text { central, the other to the local) }\end{array}$ & $\begin{array}{l}\text { VAT (not including the import link } \\
\text { customs, } 75 \% \text { of the central, local } \\
25 \% \text { ); The enterprise income tax (the } \\
\text { Ministry of Railways, the head office } \\
\text { of the bank and the offshore oil } \\
\text { enterprise pay part to the central } \\
\text { government, the remaining } 60 \% \text { of } \\
\text { the central and local } 40 \% \text { ); City } \\
\text { maintenance and construction tax } \\
\text { (the Ministry of Railways, the bank } \\
\text { head office, insurance companies } \\
\text { and other centralized payment to the } \\
\text { Central, the other to the local); } \\
\text { Stamp duty (94\% of the stamp duty } \\
\text { on securities goes to the central } \\
\text { government, the remaining } 6 \% \text { and } \\
\text { other stamp duty goes to the local) }\end{array}$ \\
\hline
\end{tabular}

Date sources: Xu Jianguo, <China's local tax system>, 10 page.

Table 2. The relationship between local tax revenue and GDP and fiscal expenditure

\begin{tabular}{cccccccc}
\hline & 2007 & 2008 & 2009 & 2010 & 2011 & 2012 & 2013 \\
\hline $\begin{array}{c}\text { National tax revenue/GDP } \\
\text { Local tax revenue/GDP }\end{array}$ & 17.16 & 17.27 & 17.46 & 18.23 & 18.97 & 19.39 & 19.43 \\
$\quad$ Local Tax Revenue/ & 4.24 & 7.41 & 7.67 & 8.14 & 8.69 & 9.12 & 9.47 \\
$\quad \begin{array}{c}\text { National Tax Revenue } \\
\text { National Tax }\end{array}$ & & 42.89 & 43.95 & 44.67 & 45.81 & 47.03 & 48.76 \\
$\begin{array}{c}\text { Revenue/National Fiscal } \\
\text { Expenditure }\end{array}$ & 91.64 & 86.63 & 78.01 & 81.46 & 82.14 & 80.04 & 78.83 \\
$\begin{array}{c}\text { Local tax revenue/local fiscal } \\
\text { expenditure }\end{array}$ & 50.22 & 47.22 & 42.85 & 44.26 & 44.33 & 44.15 & 45.01 \\
$\begin{array}{c}\text { Local fiscal expenditure/ } \\
\text { national fiscal expenditure }\end{array}$ & 77.02 & 78.68 & 80.01 & 82.21 & 84.88 & 1.26 & 85.40 \\
\hline
\end{tabular}

Date sources: The data in the table are calculated according to $<$ China Statistical Yearbook $>$. 
From the perspective of regional economic development, the traditional way of dividing China into the eastern, central, and western three regions categories is not suitable for the present economic situation, and in order better adapt to China's current economic situation and strategic plan, in this article, we will be re-divided our country into four parts in order to be closer to reality: the eastern region (Beijing, Tianjin, Hebei, Shanghai, Jiangsu, Zhejiang, Fujian, Shandong, Guangdong, Hainan, Hubei, Hunan), the western region (Inner Mongolia, Guangxi, Chongqing, Sichuan, Guizhou, Yunnan, Tibet, Shaanxi, Gansu, Qinghai, Ningxia), the northeast (Liaoning, Jilin, Heilongjiang), central (Shanxi, Anhui, Jiangxi, Xinjiang). Regional tax revenues for 2007-2013 are shown in Figures 1-4.

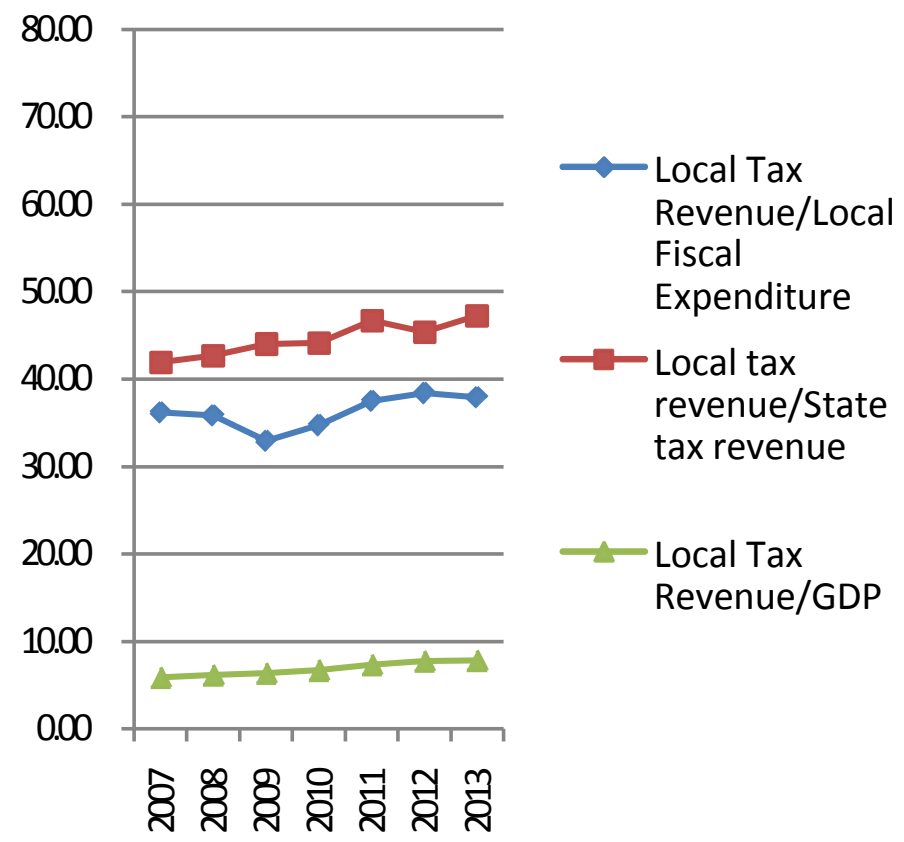

Figure 1. Eastern region.

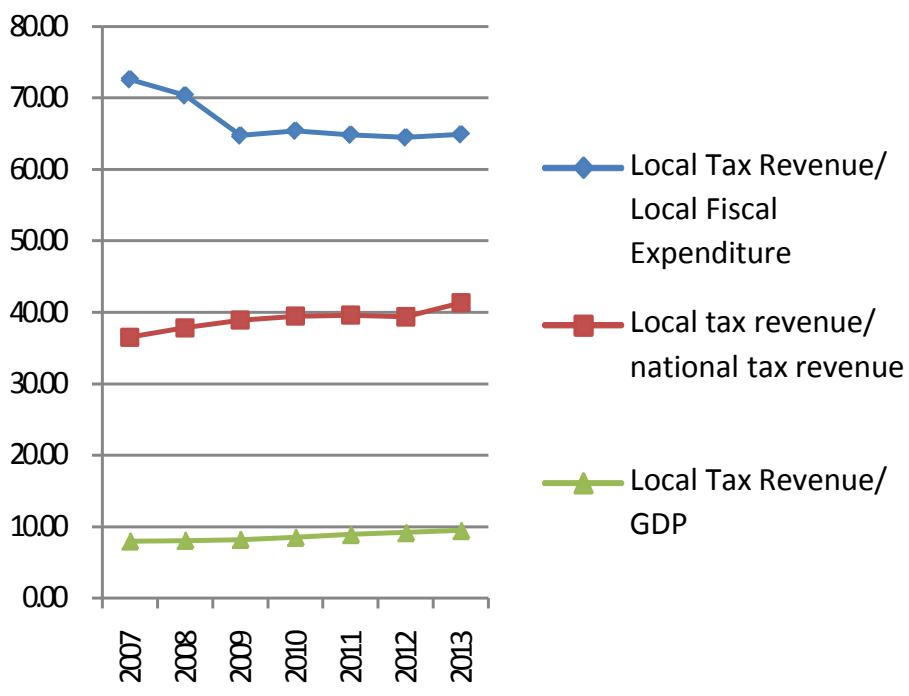

Figure 2. Northeast region. 


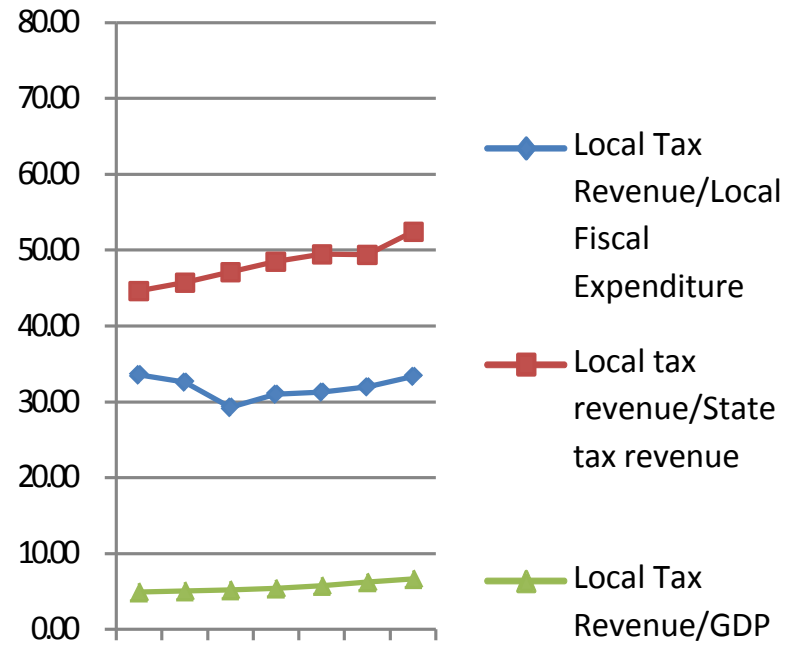

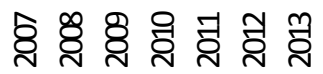

Figure 3. Central region.

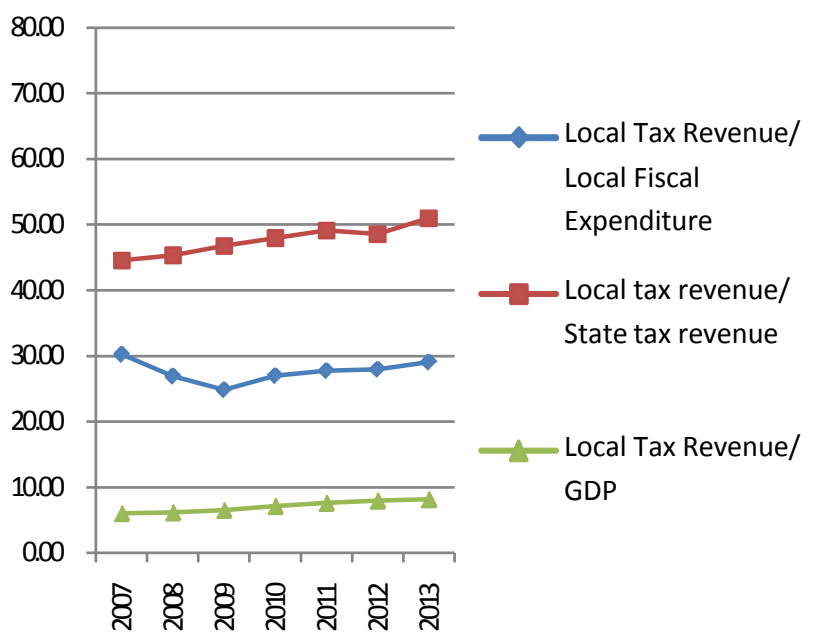

Figure 4. Western region.

As can be seen from Figures 1-4, the proportion of local tax revenue in the eastern region to local fiscal expenditure is much higher than other regions, it is indicated that the autonomous financial rights in the eastern region have a high degree of matching with the authority rights. The western region has the lowest matching degree. The ratio of local tax revenue in the eastern region to the national tax revenue is around 40 percent, much lower than in the other three regions. This is not because of the local tax revenue is small, but the eastern region is economically developed, compared with other regions, it has adequate tax sources, so it can raise large amounts of tax for the country, and so that this value is smaller. From the ratio of local tax revenue to GDP which presented the local tax revenue burden, we can see that the eastern region is higher than the northeast region and the western region, the central region is the lowest, from 
the provinces in Table 3, the specific values can also get the same conclusion.

Table 3. Local tax scale in each province of China.

\begin{tabular}{|c|c|c|c|c|c|c|c|c|}
\hline & 2007 & 2008 & 2009 & 2010 & 2011 & 2012 & 2013 & 2014 \\
\hline Beijing & 14.5801 & 15.9746 & 15.7489 & 15.9534 & 17.5649 & 17.4768 & 17.7494 & 18.1019 \\
\hline Tianjin & 8.3453 & 8.1301 & 8.1665 & 8.4195 & 8.8837 & 8.5743 & 9.0753 & 9.4544 \\
\hline Hebei & 4.5439 & 4.6771 & 4.8698 & 5.2664 & 5.5006 & 5.8724 & 6.0643 & 6.3426 \\
\hline Shanxi & 7.1459 & 7.7438 & 7.9082 & 7.5288 & 7.7675 & 8.6290 & 8.9765 & 8.8888 \\
\hline Neimenggu & 5.4165 & 5.4666 & 5.9221 & 6.4497 & 6.8642 & 7.0518 & 7.1835 & 7.0403 \\
\hline Liaoning & 7.3061 & 7.4412 & 7.7829 & 8.2171 & 8.8850 & 9.3260 & 9.2662 & 8.1413 \\
\hline Jilin & 4.4920 & 4.8407 & 4.9612 & 5.0684 & 5.9060 & 6.3703 & 6.5643 & 6.4072 \\
\hline Heilongjiang & 4.7152 & 5.0540 & 5.1742 & 5.3717 & 5.8961 & 6.1191 & 6.3149 & 6.4989 \\
\hline Shanghai & 15.8114 & 15.8028 & 15.7409 & 15.7742 & 16.5283 & 16.9797 & 17.4037 & 17.9018 \\
\hline Jiangsu & 7.2824 & 7.3550 & 7.7045 & 7.9966 & 8.3987 & 8.8471 & 9.0698 & 9.2275 \\
\hline Zhejiang & 8.1869 & 8.3498 & 8.6289 & 8.8916 & 9.1340 & 9.3112 & 9.3908 & 9.5934 \\
\hline Anhui & 5.4596 & 5.9642 & 6.2539 & 7.0113 & 7.2435 & 7.5824 & 7.9057 & 8.1181 \\
\hline Fujian & 6.4229 & 6.5088 & 6.3592 & 6.5555 & 7.1429 & 7.3107 & 7.8802 & 7.8723 \\
\hline Jiangxi & 4.8594 & 5.1350 & 5.6174 & 6.1908 & 6.6402 & 7.5534 & 8.1799 & 8.7888 \\
\hline Shandong & 5.0757 & 4.9575 & 5.0753 & 5.4887 & 5.7386 & 6.0988 & 6.3977 & 6.6734 \\
\hline Henan & 4.1633 & 4.1195 & 4.2170 & 4.4021 & 4.6901 & 4.9649 & 5.4819 & 5.5855 \\
\hline Hubei & 4.6498 & 4.7419 & 4.7531 & 4.8721 & 5.4355 & 5.9524 & 6.4733 & 6.8414 \\
\hline Hunan & 4.3504 & 4.2087 & 4.3513 & 4.5569 & 4.6539 & 5.0137 & 5.2764 & 5.3205 \\
\hline Guangdong & 7.6013 & 7.7855 & 7.9291 & 8.2661 & 8.5485 & 8.8909 & 9.2324 & 9.6011 \\
\hline Guangxi & 4.8542 & 4.9351 & 5.3831 & 5.5787 & 5.5013 & 5.8493 & 6.0605 & 6.2405 \\
\hline Hainan & 7.0158 & 8.0196 & 9.1427 & 11.4846 & 11.7214 & 12.2849 & 12.9543 & 13.7272 \\
\hline Chongqing & 6.2971 & 6.2187 & 6.6710 & 7.8425 & 8.8007 & 8.5031 & 8.7037 & 8.9874 \\
\hline Sichuan & 5.9546 & 5.8095 & 6.2657 & 6.8696 & 7.3118 & 7.6532 & 7.9702 & 8.1035 \\
\hline Guizhou & 7.3454 & 7.3226 & 7.9667 & 8.5953 & 9.0872 & 9.9480 & 10.3831 & 11.0798 \\
\hline Hainan & 7.9338 & 8.4747 & 8.8838 & 9.7196 & 9.9172 & 10.3196 & 10.2741 & 9.6236 \\
\hline Xizang & 3.4180 & 3.8470 & 4.1939 & 4.9817 & 7.5648 & 9.9953 & 8.7707 & 9.3242 \\
\hline Shanxi & 6.1748 & 6.2287 & 6.5216 & 7.0190 & 7.4634 & 7.8288 & 7.7520 & 7.5505 \\
\hline Gansu & 5.2534 & 5.1408 & 5.1967 & 5.3459 & 5.6578 & 6.1552 & 6.5985 & 7.1709 \\
\hline Qinghai & 5.4292 & 5.4878 & 6.4896 & 6.5861 & 7.1748 & 7.7469 & 8.2491 & 8.6566 \\
\hline Ningxia & 6.3964 & 6.4572 & 6.7050 & 7.5039 & 8.4259 & 8.8421 & 9.2137 & 9.0960 \\
\hline Xinjiang & 6.2628 & 6.8500 & 7.0406 & 7.6548 & 8.9774 & 9.3125 & 9.7863 & 9.5734 \\
\hline The maximum & 15.8114 & 15.9746 & 15.7489 & 15.9534 & 17.5649 & 17.4768 & 17.7494 & 18.1019 \\
\hline $\begin{array}{l}\text { Minimum } \\
\text { value }\end{array}$ & 3.4180 & 3.8470 & 4.1939 & 4.4021 & 4.6539 & 4.9649 & 5.2764 & 5.3205 \\
\hline Mean & 6.5401 & 6.7435 & 7.0202 & 7.4665 & 8.0331 & 8.4634 & 8.7291 & 8.8882 \\
\hline $\begin{array}{l}\text { Standard } \\
\text { deviation }\end{array}$ & 2.6093 & 2.7424 & 2.6843 & 2.7291 & 2.8666 & 2.8418 & 2.8417 & 2.9301 \\
\hline $\begin{array}{c}\text { Coefficient of } \\
\text { variation }\end{array}$ & 0.3990 & 0.4067 & 0.3824 & 0.3655 & 0.3569 & 0.3358 & 0.3255 & 0.3297 \\
\hline
\end{tabular}

Date sources: The data in the table are calculated according to $<$ China Statistical Yearbook $>$. National Date (http://data.stats.gov.cn/). 
Table 4. GDP and local tax revenue growth.

\begin{tabular}{ccccccccccc}
\hline & 2004 & 2005 & 2006 & 2007 & 2008 & 2009 & 2010 & 2011 & 2012 & 2013 \\
\hline GDP growth rate & 17.71 & 15.67 & 16.97 & 22.88 & 18.15 & 8.55 & 17.78 & 17.83 & 9.69 & 9.62 \\
$\begin{array}{c}\text { Local tax revenue } \\
\text { growth rate }\end{array}$ & 18.85 & 27.27 & 19.70 & 26.38 & 20.79 & 12.48 & 25.02 & 25.70 & 15.11 & 13.89 \\
$\begin{array}{c}\text { Tax elasticity } \\
1.06\end{array}$ & 1.74 & 1.16 & 1.15 & 1.15 & 1.46 & 1.41 & 1.44 & 1.56 & 1.44 \\
\hline
\end{tabular}

Note: The data in the table are calculated according to $<$ China Statistical Yearbook $>$.

From the perspective of local taxation and economic growth, although the GDP growth rate will fluctuate in different degrees every year, the overall trend is declining, from $17.71 \%$ in 2004 to $9.62 \%$ in 2013 , local tax revenue growth rate is always higher than the GDP, the tax elasticity increased from 1.06 in 2004 to 1.44 in 2013, as shown in Table 4.

\section{Hypothesis}

Based on the above analysis and combined with the actual situation in our country, to keep the macro tax burden in a reasonable scope as the premise, about the impact of local tax scale on the economy, we can put forward the following two theoretical hypothesis:

Hypothesis 1: Nationwide, China's current local tax revenue scale brings a positive effect on economic growth.

Local tax scale will affect regional economic development. When the local tax scale is small, the increase of local tax can make the local government have more financial resources to fulfill their functions, and promote the healthy development of the economy. With the expansion of local taxes, local government's power and financial rights increasingly to match with each other, the business is resolved, local construction is increasingly perfect, and the economy will have a high-speed development. If the local tax scale continues to expand beyond a certain extent, the local government revenue will too high, the funds should be efficient used will not be able to produce its efficiency in the hands of the local government, thereby causing damage to economic development, making the economic growth rate decline. As can be seen from Table 2, China's local tax revenue accounted for less than half of local fiscal expenditure, local tax revenue as the main source of local government revenue, has not been able to provide adequate financial resources to local governments. Therefore, the current scale of China's local tax is still small, the effect on economic growth should be positive.

Hypothesis 2: Within the scope of the region, China's current level of tax revenue to promote economic growth in the economically developed areas to be greater than the backward areas.

The level of economic development determines the size of tax revenue, the size of the tax will be counter-productive in economic development. Developed regions have a sound economic base and less damage to the economy when they 
raise taxes. In addition, their tax sources are sufficient to raise large amounts of tax revenue and thus have sufficient financial resources for local construction and economic development. The economic base of the backward regions is weak, the tax collection active may cause damage to the tax base, and the total economic volume in this area is small, the tax revenue raised is limited, and the financial resources of the local governments are not sufficient compare with the developed regions. So improve the local tax revenue will bring greater economic growth to the economically developed areas than the economically backward areas.

\section{Empirical Analysis}

In order to analyze the impact of local tax scale on economic growth, building the model of local economic growth under the influence of various elements including local tax revenue can make the model closer to the real economic development. Because of the factors affecting the local economic development mainly capital, labor, foreign trade, etc., to build the model to fully consider the impact of these factors on economic development, and select reasonable indicators in order to make more accurate analysis. The model is constructed as follows:

$$
\ln Y=\alpha_{0}+\alpha_{1} R T+\alpha_{2} \ln K+\alpha_{3} \ln W+\alpha_{4} R I E+\alpha_{5} R I N+\alpha_{6} R F D I+\varepsilon
$$

where $\mathrm{Y}$ is the gross national product, $\mathrm{RT}$ is the ratio of local tax revenue to gross national product, that is, local tax revenue rate. Since the factors influencing the economy are capital, labor, foreign trade, etc., here we add control variables as follows: $\mathrm{K}$ fixed asset investment (excluding farmers), $\mathrm{W}$ is the city employment population. RIE is the ratio of total imports and exports to GDP, which is used to measure the level of economic openness in a region. RIN is the ratio of the tertiary industry output to the secondary industry output in each city, representing the structure of the industry composition, RFDI for the actual use of foreign direct investment and the ratio of gross domestic product, means the contribution of foreign capital to local economic growth.

According to the data provided by the China Regional Economic Statistics Yearbook from 2008 to 2013, and the China Statistical Yearbook and the Statistical Yearbook of each province, 343 cities in China were selected as the study objects, and through the eviews6.0 using a fixed effects model of GLS regression equation, the results are shown in Table 5.

As can be seen from the regression results, for the whole country, local tax burden brought significant positive promoting effect on economic growth, Every $1 \%$ increase in local tax burden will make local economic growth rate increased by $0.0116 \%$, this may be due to: 1 ) the increase of the local taxes scale will make local governments have more financial resources to provide adequate public goods or improve the quality of public goods, and provide a favorable environment for economic operation; 2) the local government will have sufficient funds to influence the economy, play an important role in the economic macro-control, to ensure the economy running well; 3) when the local government 
Table 5. Regression analysis results.

\begin{tabular}{|c|c|c|c|c|c|}
\hline & Nationwide & East area & $\begin{array}{l}\text { North-east } \\
\text { area }\end{array}$ & $\begin{array}{l}\text { Central } \\
\text { Region }\end{array}$ & $\begin{array}{l}\text { Western } \\
\text { Region }\end{array}$ \\
\hline \multirow[t]{2}{*}{$\mathrm{C}$} & $2.98615^{\star * *}$ & $3.843531^{* * *}$ & $0.943194^{* * *}$ & $4.114384^{* * *}$ & $2.707304^{* * *}$ \\
\hline & $(31.60501)$ & $(20.15824)$ & $(2.26593)$ & $(21.39642)$ & (21.19105) \\
\hline \multirow[t]{2}{*}{ RT } & $0.011639^{* * *}$ & $0.040586^{* * *}$ & $0.037454^{* * *}$ & $0.017593^{* * *}$ & 0.001886 \\
\hline & (5.973508) & (6.491548) & (5.341724) & (4.087764) & $(1.123103)$ \\
\hline \multirow[t]{2}{*}{ LNK } & $0.497682^{* * *}$ & $0.459336^{* * *}$ & $0.436348^{* * *}$ & $0.434385^{* * *}$ & $0.510382^{\star * *}$ \\
\hline & $(127.3533)$ & $(50.69377)$ & $(21.01882)$ & $(51.12033)$ & (93.45919) \\
\hline \multirow[t]{2}{*}{ LNW } & $0.12039^{* * *}$ & $0.067752^{\star *}$ & $0.612517^{* * *}$ & -0.001562 & $0.10226^{* * *}$ \\
\hline & $(6.129305)$ & $(1.83)$ & $(7.032749)$ & $-(0.042574)$ & $(3.718001)$ \\
\hline \multirow[t]{2}{*}{ RIE } & $0.038504^{\star *}$ & $-0.069309^{\star * *}$ & 0.102604 & 0.092287 & $0.13642^{* * *}$ \\
\hline & (1.939719) & $-(2.647027)$ & $(1.222787)$ & $(0.847601)$ & $(3.842326)$ \\
\hline \multirow[t]{2}{*}{ RIN } & $-0.131171^{\star * *}$ & -0.034651 & $-0.128963^{\star * *}$ & $-0.466795^{\star * *}$ & $-0.117548^{* * *}$ \\
\hline & $-(9.254036)$ & $-(1.111616)$ & $-(2.357456)$ & $-(13.37224)$ & $-(5.663805)$ \\
\hline \multirow[t]{2}{*}{ RFDI } & $0.000504^{* * *}$ & $0.000161^{\star}$ & $5.36 \mathrm{E}-05$ & $0.004078^{* * *}$ & $0.000921^{* * *}$ \\
\hline & $(6.188176)$ & $(1.443498)$ & $(0.630222)$ & $(12.10526)$ & $(7.3774)$ \\
\hline R-squared & 0.997281 & 0.99602 & 0.996639 & 0.994802 & 0.996812 \\
\hline $\begin{array}{l}\text { Adjusted } \\
\text { R-squared }\end{array}$ & 0.996728 & 0.995167 & 0.995848 & 0.993688 & 0.996145 \\
\hline F-statistic & 1801.361 & 1167.017 & 1258.593 & 892.4946 & 1493.242 \\
\hline
\end{tabular}

1) $* * *$ indicates a significant level at $1 \%, * *$ indicates a significant level at $5 \%$, and ${ }^{*}$ indicates a significant level at $15 \%$; numbers in parentheses represent the corresponding t-values.

had sufficient income, it will not arbitrary charges, thereby reduce the interference to economic operation and national policy, the tax system will play its due role more better.

The regression result proves hypotheses one from the empirical analysis. It further shows that the scale of the overall local tax in our country has both expanded space and expanded necessity. In terms of different regions, the scale of local taxation has the greatest effect on the economic growth of the eastern region, followed by the northeast region and the central region, which has the least effect on the economic growth of the western region. The reason may be due to that the eastern region because of its geographical advantages and historical factors, it's economic development in a leading position for a long time, and consistent with the level of economic development, the public infrastructure is also more perfect, when expand the local tax revenue scale, the local government can invest more funds into high-quality public services and economic construction, so that the regional economic will developed more rapidly. In other areas, especially in the west, the economy is underdeveloped, infrastructure is not perfect, science, education, culture and health care level are far behind in the eastern region, in order to achieve the national average, those area should must invest a lot of financial resources, such as Gansu province in 2013, forestry tax, transportation expenses and housing security expenditure accounted for relatively large expenses, they were $34.66,20.79$, and 10.28 billion yuan, which is similar with the scale of the total fiscal expenditure of Gansu Provence, Tianjin's those three 
expenditures were 12.3, 9, 1.5 billion yuan, far below the level of Gansu province. This in some extent shows that when expand the scale of local tax expansion, the western regions will use more tax revenue on non-productive areas which has no direct impact on economic growth. It seems that even if the same degree of expansion of local tax scale, the eastern region's economic growth may be greater than the western region. The regression results of the four regions further support the hypothesis that the local tax size has different impacts on regional economic development, which may promote imbalanced regional development.

\section{Conclusions}

Model results show that the expansion of local tax revenue will promote China's economic growth. When enlarging the scale of local tax revenue, we should pay more attention to the following points:

First of all, to establish the reasonable scale of local tax revenue, we must ensure that China's macro tax burden in a reasonable range. Local tax revenue is an integral part of China's national tax revenue; local tax revenue and the central tax revenue together constitute a region's total tax revenue burden. Only in the premise of the reasonable size and structure of the macro tax revenue, the study of the reasonable scale of local tax revenue can be valuable. Therefore, starting from the whole tax system, carrying out tax reform, optimizing our tax system and establishing a scientific, rational and efficient tax system are the prerequisites for establishing a sound local tax system and then deciding reasonable local tax revenue.

Secondly, in the background of tax sharing system, in order to make our local tax to promote the local economic growth, not only should expand the distribution of local tax revenue, but also should be given more autonomy to local government. Since the tax reform in 1994, China's local governments have a stable source of revenue, and its proportion is growing, which has played a positive role in promoting China's local economic construction. But the expansion of local tax revenue in China is almost entirely due to changes in the economic structure of the tax base and the central government to adjust the tax structure, rather than to give the local government tax right, that is, there has only the tax segmentation, but has no division of tax authority. The tax rights concentrated in the central government, for the country as a whole can overall arrangement of tax revenue more reasonable according to the operation of the macro economy, but for the local government, it may not take into account the actual local economic development, there may appears that to some of the downturn industry has heavy taxation, and some local pillar industries because of the national support which has light tax policy and can not provide efficient tax, this will not only cause local tax and local economic development lack of correlation, which make the local governments can not take use of the local resources reasonable, distort the allocation of resources, bring bad affect to the local economic development, but also may lead to a further widening of local disparities and a more uncoordinated regional development. 
Once again, set up and perfecting the local tax system is imperative. With China increasing policy reform to promote the business tax, the tax revenue of business tax will be greatly reduced, so that it is no longer a strong support for the local government to obtain a stable and large amount of tax revenue and can no longer be the main tax of local tax system. The loss of the integrity of the local tax system will inevitably have a negative impact on the stable development of the local economy. Therefore, in the new round of tax system construction, we should establish a new major local tax, and optimize the existing local tax system, such as the introduction of resources tax, establish and perfect the local tax system, to adapt to the development of economy and society.

Finally, increase the transfer payments to the backward areas, improve their basic public services, and reduce the regional economic development differences. Due to historical and geographical factors, the economic disparities in various regions of our country have become objective facts. Improving the local tax system, giving the local government more independent tax rights, is bound to promote economic development, but also will produce regional development speed inconsistency, and further increase the gap between east and west region, this will require the government to increase its financial and policy support to the western region, to rapidly develop infrastructure construction in backward areas and raise the level of its public services so that this district can devote more funds to economic development and narrow the gap with other regions.

This paper starts with the relationship between local taxation and economic growth, and explores the relationship between local taxation and economic growth from a new perspective. But the article also has some shortcomings. Because of the large sample of empirical research used in this paper, the data from a variety of statistical yearbook and statistical website, there may be different indicators in different years of statistical caliber inconsistent and provincial statistics between the different caliber, resulting in different statistical results, so as far as possible the article use of China's regional economic statistics in the effective data in order to improve the accuracy of the model results. Moreover, due to the limited data, this article in the measurement analysis can be selected when the year is more limited, may lead to research results have some limitations.

In summary, the expansion of local tax revenue is not a simple increase in local tax revenue, it should combined with the effect of scientific tax allocation and a reasonable tax system to increase the size of the tax. Only in this way can we make rational use of local tax revenue to promote economic development.

\section{References}

[1] Koester R.B. and Kormendi R.C. (1989) Taxation, Aggregate Activity and Economic Growth: Cross-Country Evidence on Some Supply Side Hypotheses. Economic Inquiry, 27, 367-387. https://doi.org/10.1111/j.1465-7295.1989.tb02011.x

[2] Marsden, K. (1983) Links between Taxes and Economic Growth: Some Empirical Evidence. Word Bank Staff Working Papers, No. 605, 21-25.

[3] Karras. G. (1999) Taxes and Growth: Testing the Neoclassical and Endogenous Growth Models. Contemporary Economic Policy, 17, 177-195. 
https://doi.org/10.1111/j.1465-7287.1999.tb00673.x

[4] Scully, G.W. (1995) The Growth tax in the United States. Public Choice, 85, 71-80. https://doi.org/10.1007/BF01047902

[5] Scully, G.W. (1996) Taxation Rate and Economic Growth in Zealand. Pacific Economic Review, 14, 169-177. https://doi.org/10.1111/j.1468-0106.1996.tb00182.x

[6] Guo, Q.W. and Lv, B.Y. (2004) The Negative Impact of Tax Increase on Economic Growth. Economic Theory and Economic Management, No. 8, 18-23.

[7] Wang, J.P. (2005) Study on the Relationship between Macro Tax Burden and Economic Growth. Journal of Shanxi University of Finance and Economics, No. 4, 35-38.

[8] Xu, J.G. and Ye, Q. (1998) Reasonable Local Tax Scale: Theory and Empirical Analysis. Public Finance Research, No. 11, 37-45.

[9] Shi, Y.Q. and Ma, L. (1998) Analysis and Countermeasures of Local Tax Revenue in Proportion to GDP. Taxtion Research Journal, No. 7, 34-38.

[10] Li, D., Cao, J.X. and Yang, M. (2006) Study on the Relationship between Local Tax Growth and Economic Growth in Guangdong Province. International Taxation in China, No. 9, 13-17.

[11] Ma, S.Y. (2001) Local Taxation and the Development of the Western Region: An Empirical Analysis of Marginal Tax Rate and Regional Economic Development. International Taxation in China, No. 1, 7-10.

\section{Submit or recommend next manuscript to SCIRP and we will provide best} service for you:

Accepting pre-submission inquiries through Email, Facebook, LinkedIn, Twitter, etc. A wide selection of journals (inclusive of 9 subjects, more than 200 journals)

Providing 24-hour high-quality service

User-friendly online submission system

Fair and swift peer-review system

Efficient typesetting and proofreading procedure

Display of the result of downloads and visits, as well as the number of cited articles

Maximum dissemination of your research work

Submit your manuscript at: http://papersubmission.scirp.org/

Or contact me@scirp.org 